\title{
Anthropometric and metabolic pattern in obese Egyptian children: its association with C-reactive protein
}

\author{
Nageh S. Mohamed ${ }^{1}$, Sheren Esam Maher ${ }^{1 *}$, Samah M. M. Abozaid ${ }^{2}$ and Hend M. Moenes ${ }^{3}$
}

\begin{abstract}
Background: Obesity is the most common chronic metabolic disease in children. The global prevalence of obesity has doubled from 1990 to 2015. Worryingly, the increase is more in children than adults. It has reached epidemic ranges and is a significant global problem. High-sensitivity C-reactive protein (hs-CRP) is a parameter that is used to assess inflammation and risk factor for cardiovascular events. Some reports describe an association between hs-CRP and obesity. The objective of the study is to evaluate anthropometric and metabolic parameters in obese Egyptian children and correlate them with hs-CRP level.

Results: For anthropometric variables, they were significantly higher in obese group than normal weight except for height ( $P$ value 0.001). A significant difference was reported for all lipid profile parameters between obese and normal-weight groups ( $P$ value 0.001 ). Also, CRP showed a positive correlation with both BMI as well as total cholesterol, while no correlation was observed with other parameters of obesity (r: $0.41,0.29$ respectively).

Conclusion: Elevated CRP may have a role in predicting altered lipid metabolism in obese children and this raises the possibility of cardiovascular diseases. Hence, preventive measures to control obesity is necessary.
\end{abstract}

Keywords: Childhood obesity, Blood pressure, Serum lipid profile, CRP

\section{Background}

The global prevalence of obesity has doubled from 1990 to 2015 . Worryingly, the increase is more in children than in adults. In just three decades, the number of school-going children and adolescents with obesity has increased by tenfold, and the International Association for the Study of Obesity and International Obesity Task Force reckon that 200 million school children worldwide are either overweight or obese [1]. Children and adolescents who were obese from childhood to adulthood were associated with increased risk of many metabolic abnormalities and type 2 diabetes mellitus, suggesting that obese individuals show an unfavorable metabolic profile that is associated with high cardiovascular risk $[2,3]$. Cardiovascular risk factors including combined dyslipidemia, insulin resistance and hypertension. Also, it is associated with low-grade systemic inflammation. High-sensitivity C-reactive protein (hsCRP) is a parameter that is used to assess inflammation, and it is a risk factor for cardiovascular events [10] and elevated arterial stiffness [11]. Moreover, several reports have described an association between carotid atherosclerosis and hs-CRP [4].

Many studies demonstrated that the atherosclerotic process starts without symptoms during childhood [5]. And if risk factors are identified early and the corrective steps are taken, the process can be delayed [6].

This study was carried out to evaluate anthropometric and metabolic parameters in obese Egyptian children and correlate them with CRP level.

\footnotetext{
* Correspondence: sherenesammaher@yahoo.com

${ }^{1}$ Pediatric Department, Minia University, Minia, Egypt

Full list of author information is available at the end of the article
}

\section{Springer Open}

(- The Author(s). 2020 Open Access This article is licensed under a Creative Commons Attribution 4.0 International License, which permits use, sharing, adaptation, distribution and reproduction in any medium or format, as long as you give appropriate credit to the original author(s) and the source, provide a link to the Creative Commons licence, and indicate if changes were made. The images or other third party material in this article are included in the article's Creative Commons licence, unless indicated otherwise in a credit line to the material. If material is not included in the article's Creative Commons licence and your intended use is not permitted by statutory regulation or exceeds the permitted use, you will need to obtain permission directly from the copyright holder. To view a copy of this licence, visit http://creativecommons.org/licenses/by/4.0/. 


\section{Methods \\ Sample}

This is a case-control study carried out in outpatient clinic of pediatrics in Minia maternity and children hospital, through the period from March 2018 to June 2019. This study involved a population of one hundred children (47 females and 53 males) with an age range between 6-12 years, 50 children only with simple overweight as cases; the obesity was defined according to the sex- and age-specific growth charts proposed by National Research Center as BMI $\geq 95$ th percentile and other 50 age-matched nonobese (BMI between 25th and 85th percentile) children as controls. All participants were apparently healthy and exclusion criteria were as follows: diabetes, secondary causes of obesity, chronic diseases or chronic medication as steroids, and acute infection. Written informed consent was obtained from the guardians of each participant after explaining the aim of the study and the study approved by the ethical committee of Minia University, Egypt.

\section{Anthropometric measurements}

All the measurements were taken while participants were without shoes for height measurements and without sweater and jackets for weighing.

The following data were collected: personal (sex and date of birth), anthropometric (weight, height, waist, and hip measurements) were taken. Derived values were calculated according to standardized formulas (Table 1).

The definitions for being obese were derived from the anthropometric measurement based on the calculation of body mass index [7].

\section{Biochemical parameters}

- Blood samples were taken early in the morning with the participants fasting (minimum $12 \mathrm{~h}$ ). Lipid

Table 1 Anthropometric variables and derived values in the present study: technique of measurements or equation for calculation

\begin{tabular}{|c|c|}
\hline Measurements & Equipment, technique, or equation \\
\hline Weight & $\begin{array}{l}\text { Using standard weighing scale } \\
\text { (to the nearest } \mathrm{kg} \text { ) }\end{array}$ \\
\hline Height & Using a stadiometer (to the nearest $\mathrm{cm}$ ) \\
\hline $\begin{array}{l}\text { Waist circumference } \\
\text { (WC) }\end{array}$ & $\begin{array}{l}\text { By applying the non-stretchable tape at the } \\
\text { midway level between the highest point of the } \\
\text { iliac crest and costal margin at quiet } \\
\text { respiration [8] }\end{array}$ \\
\hline $\begin{array}{l}\text { Hip circumference } \\
(\mathrm{HC})\end{array}$ & $\begin{array}{l}\text { By applying the non-stretchable tape at the level } \\
\text { of the highest protrusion of the buttocks [9] }\end{array}$ \\
\hline $\begin{array}{l}\text { Body mass index } \\
\text { (BMI) }\end{array}$ & $\begin{array}{l}\text { BMI = body weight (in } \mathrm{kg} \text { ) divided by (height })^{2} \\
\left(\mathrm{in}^{2}\right)^{2} \text { [7] }\end{array}$ \\
\hline $\begin{array}{l}\text { Waist to hip ratio } \\
\text { (WHR) }\end{array}$ & $\begin{array}{l}\text { WHR = waist circumference (in } \mathrm{cm} \text { ) divided by } \\
\text { hip circumference (in } \mathrm{cm} \text { ) [8] }\end{array}$ \\
\hline
\end{tabular}

profile was determined by the enzymatic colorimetric method (Eli Tech Clinical Systems). TC and TG were determined using the Trinder method (intra-assay coefficient of variation of $1.35 \%$ and $2.58 \%$, respectively) and HDL-C intra-assay coefficient of variation (2.32\%) using the method of selective accelerating detergent (Mindray BS120). LDL-C was calculated from the previously mentioned lipids by means of the Friedewald formula [10]. Measurement of CRP was done by the method based on particle enhanced turbidimetric immunoassay (PETIA) technique.

- hs-CRP levels less than $1 \mathrm{mg} / \mathrm{dL}$ are considered low risk. Levels between $1 \mathrm{mg} / \mathrm{dL}$ and $3 \mathrm{mg} / \mathrm{dL}$ are considered moderate risk and a level greater than 3 $\mathrm{mg} / \mathrm{dL}$ is considered high risk for the development of cardiovascular disease [11].

\section{Blood pressure}

Measurements were taken using a mercury sphygmomanometer and the results were plotted on sex-specific SBP and DBP percentiles [12].

\section{Statistical analysis}

Data analysis was done using the SPSS statistical package version 20. Mean and standard deviations were obtained for anthropometric indices and derived values of both sexes. Student $t$ test was done to establish the presence of significant sexual differences. $P$ value less than 0.05 considered as statistically significant. Pearson's correlation coefficient was done to test the association between CRP, blood pressure, and metabolic parameters.

\section{Results}

A total of 100 participants were included 53 boys and 47 girls with a mean age $(8.6 \pm 3.4$ and $8.7 \pm 3.1)$ for control and obese group respectively.

Table 2 showed a non-significant difference between obese and normal-weight group as regarding age, height, W/hip ratio and SBP. For other anthropometric variables, they were significantly higher in the obese group than normal weight. DBP and metabolic parameters were significantly higher in the obese group than those of normal weight group except for HDL which was significantly lower in the obese group.

The participant's BP was mostly in the normal range, the percentage of participants with a normal BP in the normal and obese groups was $52.28 \%$ and $47.72 \%$, respectively. The highest percentage of total cholesterol was found in "high" category in obese children (66.66\%). The highest percentage of triglyceride was found in "high" category in obese children (56.7\%). The most prevalent LDL$\mathrm{C}$ group was obese children in the "high" range at $62.5 \%$ and the highest percentage of participants in terms of 
Table 2 Statistical differences in anthropometric measures, blood pressure, and metabolic parameters in normal weight and obese children

\begin{tabular}{llll}
\hline & Normal weight $(N=50)$ & Obese $(N=50)$ & $P$ value \\
\hline Age & $8.6 \pm 3.1$ & $8.56 \pm 3.57$ & 0.33
\end{tabular}

Anthropometric

measures

\begin{tabular}{llll} 
Weight/kg & $31.92 \pm 10.88$ & $52.81 \pm 19.56$ & 0.0001 \\
Height/cm & $135.82 \pm 21.02$ & $134.36 \pm 20.23$ & 0.79 \\
BMl (kg/m²) & $19.47 \pm .97$ & $32.14 \pm 1.89$ & 0.001 \\
WC/cm & $55.16 \pm 4.14$ & $87.64 \pm 4.95$ & 0.001 \\
HC/cm & $69.68 \pm 8.04$ & $89.79 \pm 10.21$ & 0.001 \\
WHR & $0.81 \pm 0.06$ & $0.91 \pm 0.07$ & 0.28 \\
Blood pressure & & & \\
SBP (mmHg) & $99.63 \pm 9.45$ & $109.84 \pm 8.91$ & 0.68 \\
DBP (mmHg) & $63.12 \pm 6.13$ & $72.68 \pm 8.15$ & 0.048 \\
Metabolic profile & & & \\
TC (mg/dl) & $141.73 \pm 37.26$ & $169.64 \pm 25.04$ & 0.006 \\
HDL (mg/dl) & $61.42 \pm 9.01$ & $47.59 \pm 16.13$ & 0.001 \\
LDL (mg/dl) & $85.74 \pm 1.14$ & $109.35 \pm 35.12$ & 0.001 \\
TG (mg/dl) & $98.26 \pm 9.72$ & $129.84 \pm 26.48$ & 0.001 \\
hs-CRP & $2.2 \pm 1.16$ & $4.19 \pm 1.94$ & 0.001 \\
Hb A1c & $4.98 \pm 1.24$ & $5.11 \pm 0.45$ & 0.001 \\
\hline
\end{tabular}

$B M I$ body mass index, WC waist circumference, WHR waist to hip ratio, SBP systolic blood pressure, DBP diastolic blood pressure, TC total cholesterol, HDL$C$ high-density lipoprotein cholesterol, LDL-C low-density lipoprotein cholesterol, $T G$ triglyceride, $h s-C R P$ high-sensitive C-reactive protein, HbA1c glycated hemoglobin

HDL-C was obese children in the "borderline" category at 75\% (Table 3).

Children were divided into three subcategories based on their hs-CRP levels $(<1,1-3$, and $>3 \mathrm{mg} / \mathrm{L})$ and there was a highly significant difference between the two studied groups (Table 4).

Statistical analysis of the anthropometric measures, blood pressure, and metabolic parameters for obese children with hs-CRP $<$ 3and those with CRP $>3$ revealed that all variables showed insignificant difference except for waist circumference and waist/hip ratio (Table 5).

Correlation between hs-CRP and other parameters revealed that in the obese group, both BMI and TC showed a positive significant correlation with hs-CRP levels while no correlation was observed between hsCRP and other parameters of obesity (Table 6).

\section{Discussion}

The high prevalence of obesity has become a major global health challenge, since obesity is associated with severe health consequences, contributing to the increase in cardiovascular morbidity and mortality [1].
The present study was done on two groups of comparable age and sex: obese children and control group of normal-weight children. Regarding age and gender, the study revealed no significant difference between both groups. This is similar to the results reported by Pyke [13] who found no significant difference between boys' and girls' obesity. Also, Bahar et al. [14] reported no significant difference in serum lipid levels between the boys and the girls in any age group. On the other hand, LaFrance et al. [15] found that boys' obesity was higher than girls' obesity. These differences may be due to the difference in localities, sample size, cultural, and/or socioeconomic causes, and BMI is the most frequently used measure of weight in relation to height. It has been described as the backbone of the obesity classification system and surveillance statistics. In the present study, we found that the BMI was significantly higher in obese children as compared to normal-weight children. Although BMI does not distinguish between weight associated with muscle and weight associated with fat [16]. On the other hand, data of prospective studies showed that each increase of $5 \mathrm{~kg} / \mathrm{m}^{2}$ in BMI was associated with $40 \%$ higher cardiovascular mortality [17]. Anthropometric measurements are non-invasive and inexpensive method to assess patients' nutritional status and have been suggested for wide use in clinical practice [9]. Measuring abdominal circumference in addition to general obesity has been recommended in order to improve cardiometabolic risk assessment. As the pattern of fat distribution has been shown to have a large influence on cardiometabolic risk and as a result, abdominal obesity seems to predict the development of cardiovascular diseases better than overall obesity [18]. Waist circumference is an indicator of the distribution of abdominal or visceral fat, and also is an indicator for insulin resistance, type 2 diabetes, dyslipidemia, and cardiovascular disease in the form of high blood pressure in childhood and adulthood [19]. In the present study, WC was significantly higher in the obese group than the normal weight one. This is in accordance with the International Diabetes Federation has recommended including WC as a screening marker of abdominal obesity in children and has defined WC as one of the risk criteria for metabolic syndrome in children > 10 years old [20]. Also, it was observed that obese individuals had higher nonsignificant WHR levels than those with a normal weight. The mean systolic BP did not differ significantly among the two study groups; however, the mean diastolic BP showed a significant difference. Obese children had higher diastolic blood pressure than normal-weight children, by $9.56 \mathrm{~mm} \mathrm{Hg}$. In the present study, two of the obese group was actually hypertensive. These results in accordance with studies conducted in Shanghai, China, the Caribbean, and Turkey, which all indicated that 
Table 3 Sample distribution by lipid profile and blood pressure in normal weight and obese children

\begin{tabular}{|c|c|c|c|}
\hline Variables & Normal weight $(N=50)$ & Obese $(N=50)$ & Total $(N=100)$ \\
\hline \multicolumn{4}{|l|}{ Blood pressure } \\
\hline Normal (<90th percentile) & $47(52.8 \%)$ & $42(47.2 \%)$ & $89(100 \%)$ \\
\hline Pre-hypertensive (90-95th percentile) & $3(33.33 \%)$ & $6(66.66 \%)$ & $9(100 \%)$ \\
\hline Hypertensive (> 95th percentile) & 0 & $2(100 \%)$ & $2(100 \%)$ \\
\hline \multicolumn{4}{|l|}{ Total cholesterol (mg/dl) } \\
\hline Acceptable $(<170)$ & $39(54.92 \%)$ & $32(45.08 \%)$ & $71(100 \%)$ \\
\hline Borderline (170-199) & $8(40 \%)$ & $12(60 \%)$ & $20(100 \%)$ \\
\hline High ( $\geq 200)$ & $3(33.33 \%)$ & $6(66.66 \%)$ & $9(100 \%)$ \\
\hline \multicolumn{4}{|l|}{ Triglyceride } \\
\hline Acceptable $(<90)$ & $20(62.5 \%)$ & $12(37.5 \%)$ & $32(100 \%)$ \\
\hline Borderline (90-129) & $17(44.7 \%)$ & $21(55.3 \%)$ & $38(100 \%)$ \\
\hline High ( $\geq 130)$ & $13(43.3 \%)$ & $17(56.7 \%)$ & $30(100 \%)$ \\
\hline \multicolumn{4}{|l|}{$\mathrm{HDL}-\mathrm{C}(\mathrm{mg} / \mathrm{dl})$} \\
\hline Acceptable (> 45) & $42(60 \%)$ & $28(40)$ & $70(100 \%)$ \\
\hline Borderline (40-45) & $5(25 \%)$ & $15(75 \%)$ & $20(100 \%)$ \\
\hline High $(<40)$ & $3(30 \%)$ & $7(70 \%)$ & $10(100 \%)$ \\
\hline \multicolumn{4}{|l|}{ LDL-C (mg/dl) } \\
\hline Acceptable $(<110)$ & $36(55.4 \%)$ & $29(44.6 \%)$ & $65(100 \%)$ \\
\hline Borderline (110-129) & $11(40.7 \%)$ & $16(59.6 \%)$ & $27(100 \%)$ \\
\hline High ( $\geq 130$ ) & $3(37.5 \%)$ & $5(62.5 \%)$ & $8(100 \%)$ \\
\hline
\end{tabular}

overweight and obese children had higher BP [21, 22]. Obesity predisposes to hypertension because of concomitant metabolic and hemodynamic abnormalities leading to inadequate lowering of systemic resistance and, therefore, to more severe cardiovascular burden [23]. Many of cardiovascular complications related to obesity may begin in childhood and adolescence. Furthermore, it has been shown that obesity is associated with the development of early myocardial and coronary artery changes in children [24]. Hypertension may also increase cardiovascular risk by causing chronic endothelial injury promoting structural and functional vascular alterations, especially in the microvascular network [25].

Dyslipidemia is a fat metabolism disorder that occurs as a result of the interaction between genetic and environmental factors. Regarding lipid profile, there was no significant difference between obese girls and boys, but LDL, serum TG, and serum TC were significantly higher in obese children as compared to control. However, HDL was significantly lower in obese as compared to normal-weight children.

Table 4 hs-CRP levels in normal weight and obese children

\begin{tabular}{llllll}
\hline hs-CRP levels & $<1 \mathrm{mg} / \mathrm{L}$ & $1-3 \mathrm{mg} / \mathrm{L}$ & $>3 \mathrm{mg} / \mathrm{L}$ & $X^{2}$ & $P$ value \\
\hline Normal weight group & 2 & 42 & 6 & 12.74 & 0.002 \\
Obese group & 1 & 27 & 22 & & \\
\hline
\end{tabular}

This was in accordance with Kim et al. [26] found that all types of lipids were significantly associated with obesity. Also, Horri and Vakil [26, 27] stated that serum TG and cholesterol levels were significantly higher in obese children and adolescents. In addition, HDL-cholesterol was significantly lower in the obese children than control. Total cholesterol levels in the blood are greatly affected by a person's food intake. Diets high in saturated fat can raise the levels of total cholesterol in the blood stream. Also saturated fats, carbohydrates can affect total cholesterol levels [28].

A study on overweight and obese children indicated that high sedentary activity is associated with low HDL$\mathrm{C}$ [21] which is a known risk factor for cardiovascular disease. In the present study, 22 subjects out of 50 of the obese group were having CRP more than $3 \mathrm{mg} / \mathrm{L}$. This high level of CRP obtained was probably a reflection of presence of subclinical inflammation. As all participants were examined systemically to rule out any recent infection or other inflammatory states. A positive significant correlation was observed between BMI and CRP levels in obese children, but the same degree of correlation was not seen between CRP and other anthropometric measurements. Earlier studies also have shown similar positive correlation between BMI, WC, and CRP [29]. Although obese children had significant differences in lipid levels as compared to controls, the correlation 
Table 5 Anthropometric and biochemical characteristics of the obese children according to hs-CRP level

\begin{tabular}{|c|c|c|c|}
\hline Parameters & With hs-CRP < $3(N=28)$ & With hs-CRP > $3(N=22)$ & $P$ value \\
\hline Age (years) & $8.41 \pm 3.57$ & $8.51 \pm 3.44$ & 0.87 \\
\hline \multicolumn{4}{|c|}{ Anthropometric measures } \\
\hline Weight (kg) & $49.87 \pm 18.45$ & $51.57 \pm 19.64$ & 0.75 \\
\hline Height (cm) & $129.78 \pm 24.43$ & $133.58 \pm 22.65$ & 0.73 \\
\hline $\mathrm{BMI}\left(\mathrm{kg} / \mathrm{m}^{2}\right)$ & $31.54 \pm 3.04$ & $32.15 \pm 2.17$ & 0.12 \\
\hline WC $(\mathrm{cm})$ & $87.14 \pm 3.11$ & $87.31 \pm 4.84$ & 0.03 \\
\hline $\mathrm{HC}(\mathrm{cm})$ & $86.24 \pm 7.32$ & $88.82 \pm 10.24$ & 0.64 \\
\hline WHR & $0.88 \pm 0.11$ & $0.91 \pm 0.02$ & $<0.001$ \\
\hline \multicolumn{4}{|l|}{ Blood pressure } \\
\hline $\operatorname{SBP}(\mathrm{mmHg})>120$ & $111.02 \pm 8.04$ & $109.97 \pm 9.87$ & 0.32 \\
\hline $\mathrm{DBP}(\mathrm{mmHg})>70$ & $72.33 \pm 7.92$ & $73.87 \pm 8.04$ & 0.93 \\
\hline \multicolumn{4}{|l|}{ Metabolic profile } \\
\hline $\mathrm{HDL}-\mathrm{C}(\mathrm{mg} / \mathrm{dL})$ & $47.27 \pm 13.67$ & $41.02 \pm 11.64$ & 0.45 \\
\hline LDL-C (mg/dL) & $104.95 \pm 29.87$ & $108.24 \pm 31.45$ & 0.79 \\
\hline $\mathrm{TG}(\mathrm{mg} / \mathrm{dL})$ & $116.54 \pm 23.64$ & $124.33 \pm 21.57$ & 0.67 \\
\hline $\mathrm{TC}(\mathrm{mg} / \mathrm{dL})$ & $169.37 \pm 19.83$ & $174.12 \pm 21.45$ & 0.69 \\
\hline $\mathrm{Hb} \mathrm{A} 1 \mathrm{c}$ & $5.75 \pm 0.81$ & $6.13 \pm 0.65$ & 0.62 \\
\hline
\end{tabular}

$B M I$ body mass index, WC waist circumference, WHR waist to hip ratio, SBP systolic blood pressure, $D B P$ diastolic blood pressure, $H D L-C$ high-density lipoprotein cholesterol, LDL-C low-density lipoprotein cholesterol, TG triglyceride, TC total cholesterol, HbA1c glycated hemoglobin

between CRP and parameters of lipid profile in the present study was not significant except for total cholesterol. The adverse cardiovascular risk profile in obese individuals is characterized by high blood pressure, dyslipidemia, and hyperglycemia, elevated level of CRP and a higher level of other biomarkers of cardiovascular risk [30].

Table 6 Correlation analysis between hs-CRP and other parameters for the study group

\begin{tabular}{|c|c|c|}
\hline & $\begin{array}{l}\text { Pearson correlation } \\
\text { coefficient }\end{array}$ & $P$ value \\
\hline Age (years) & -0.99 & 0.42 \\
\hline Weight & 0.14 & 0.14 \\
\hline Height & 0.24 & 0.64 \\
\hline BMI (kg/m2) & 0.41 & 0.02 \\
\hline WC & 0.31 & 0.08 \\
\hline WHR & 0.12 & 0.19 \\
\hline SBP & 0.06 & 0.72 \\
\hline DBP & -0.04 & 0.61 \\
\hline $\mathrm{TC}(\mathrm{mg} / \mathrm{dL})$ & 0.29 & 0.04 \\
\hline $\mathrm{HDL}-\mathrm{C}(\mathrm{mg} / \mathrm{dL})$ & 0.13 & 0.14 \\
\hline LDL-C (mg/dL) & 0.11 & 0.39 \\
\hline $\mathrm{Hb} \mathrm{A} 1 \mathrm{c}$ & 0.08 & 0.62 \\
\hline
\end{tabular}

$B M I$ body mass index, $W C$ waist circumference, $W H R$ waist to hip ratio, $S B P$ systolic blood pressure, DBP diastolic blood pressure, TC total cholesterol, HDL$C$ high-density lipoprotein cholesterol, LDL-C low-density lipoprotein cholesterol, HbA1c glycated hemoglobin

\section{Conclusion}

Elevated hs-CRP may have a role in predicting altered lipid metabolism in obese children and this raises the possibility of cardiovascular diseases. Hence, preventive measures to control obesity are necessary.

Obese children exhibit several risk factors for the development of cardiovascular diseases, and that metabolic syndrome is already a reality for many children, being present in $27.3 \%$ of the obese children investigated here. Exercise intervention reduces CRP, may be effective in preventing the occurrence of cardiovascular events.

\section{Abbreviations}

BMI: Body mass index; WC: Waist circumference; WHR: Waist to hip ratio; SBP: Systolic blood pressure; DBP: Diastolic blood pressure; TC: Total cholesterol; HDL-C: High-density lipoprotein cholesterol; LDL-C: Low-density lipoprotein cholesterol; HbA1c: Glycated hemoglobin

\section{Acknowledgements \\ None \\ Authors' contributions}

N S: Making substantial contributions to conception, design, or analysis and interpretation of data.S E: Involvement in drafting the manuscript and revising it for important intellectual content, corresponding author. S M: Analyzed and interpreted the patients data. $\mathrm{H}$ M: Performance of methodology, lab investigation. All authors read and approved the final manuscript.

\section{Funding}

This research did not receive any specific grant from funding agencies in the public, commercial, or not-for-profit sectors. 


\section{Availability of data and materials}

The datasets used and/or analyzed during the current study are available from the corresponding author on reasonable request.

\section{Ethics approval and consent to participate}

The study approved by ethical committee of Minia University, Faculty of Medicine, Egypt (approval no.862/27-12-2017).

\section{Consent for publication}

Not applicable

\section{Competing interests}

None

\section{Author details}

${ }^{1}$ Pediatric Department, Minia University, Minia, Egypt. ${ }^{2}$ Anatomy Department, Minia University, Minia, Egypt. ${ }^{3}$ Clinical Pathology Department, Minia University, Minia, Egypt.

Received: 8 January 2020 Accepted: 29 May 2020

Published online: 06 July 2020

\section{References}

1. Vangal Krishnaswamy, Puja Dudeja (2020). Obesity in school children in India.DOI:10-5772,intech open 89602

2. Misra A, Khurana L (2008) Obesity and the metabolic syndrome in developing countries.J. Clin Endocrinol Metab 93(1):S9-S30

3. Juonala M, Magnussen CG, Berenson GS et al (2011) Childhood adiposity, adult adiposity, and cardiovascular risk factors. N Engl J Med 365(20):1876-1885

4. - -jima, S., Kubozono, T., Kawasoe, S. et al. (2020) Association of risk factors for atherosclerosis, including high-sensitivity C-reactive protein, with carotid intima-media thickness, plaque score, and pulse wave velocity in a male population. Hypertens Res . https://doi.org/https://doi.org/10.1038/s41440019-0388-2

5. Ml C, Weigensberg MJ, Huang TT, Ball G, Shaibi GQ, Goran MI (2004) The metabolic syndrome in overweight Hispanic youth and the role of insulin sensitivity. J Clin Endocrinol Metab 89:108-113

6. Yung SI (2009) Consequences of childhood obesity. Ann Acad Med Singap 38:75-78

7. Lucile LA, Nwankwo M, Ukoli F, Omene J, Halie GT, Kuller LH (1990) J Natl Med Assoc 82(8):573-576

8. World Health Organization (WHO) (2008). Waist circumference and waist-hip ratio: report of a WHO expert consultation Geneva, 8-11 December (2008)

9. Mxhosa TH, Mgoduka PN, Nkeh-Chungag BN (2015) Association of waist and hip circumferences with the presence of hypertension and prehypertension in young south African adults. Afr Health Sci 15(3):908-916

10. Lopes-Virella MF, Stone P, Ellis S (1977) Cholesterol determination in HDL separated by three different methods. J ClinChem 23:88-92

11. Johns I, Moschonas KE, Medina J, Ossei-Gerning N, Kassianos G, Halcox JP (2018) Risk classification in primary prevention of CVD according to QRISK2 and JBS3 'heart age', and prevalence of elevated high-sensitivity $C$ reactive protein in the UK cohort of the EURIKA study. Open Heart 5(2):e000849

12. Pickering TG, Hall JE, Appel LJ, Falkner BE, Graves J, Hill MN, Jones DW, Kurtz T, Sheps SG, Roccella EJ (2005) Recommendations for blood pressure measurement in humans and experimental animals, part 1: blood pressure measurement in humans: a statement for professionals from the Subcommittee of Professional and Public Education of the American Heart Association Council on high blood pressure research. Hypertension. 45:142161. https://doi.org/10.1161/01.HYP.0000150859.47929.8e

13. Pyke J (1985) Australian health and fitness survey. Australian Council for Health, Physical Education and Recreation Inc., Adelaide, SA

14. Bahar A, Sevgican U, Karademir F, Gocmen I (2003) Serum cholesterol, triglyceride, VLDL-C, LDL-C, and HDL-c levels in healthy children. Tohoku J Exp Med 201:75-80

15. LaFrance S, Nolan M, Page J et al (2005) New Hampshire childhood obesity report, foundation for healthy community.

16. World Health Organization (WHO) (2006) Child growth standards. Length/ height-for-age, weight- for-age, weight-for-length, weight-for-height, and body mass index-for-age. Methods and development. World Health Organization, Geneva

17. Whitlock G, Lewington S, Sherliker P, Clarke R, Emberson J et al (2009) Body mass index and cause-specific mortality in 900000 adults: collaborative analyses of 57 prospective studies. Lancet 373:1083-1096

18. Siren R, Eriksson JG, Vanhanen H (2012) Waist circumference a good indicator of future risk for type 2 diabetes and cardiovascular disease. BMC Public Health 12:631-637

19. Ball GD, Huang TT, Cruz ML, Shaibi GQ, Weigensberg MJ, Goran MI (2006) Predicting abdominal adipose tissue in overweight Latino youth. Int J PediatrObes 1:210-216

20. Zimmet $P$, Alberti KG, Kaufman F, Tajima N, Silink M, Arslanian S, Wong G, Bennett P, Shaw J, Caprio S, IDF Consensus Group (2007) The metabolic syndrome in children and adolescents - an IDF consensus report. Pediatr Diabetes 8(5):299-306

21. Simunovic M, Bozic J, Milic L, Unic I, Skarabic V (2016) The prevalence of metabolic syndrome and cardiovascular risk factors in obese children and adolescents in Dalmatia: a hospital based study. Int J Endocrinol 22:1888-1895

22. Taheri F, Kazemi T, Bijari B, Namakin K, Zardast M, Chahkandi T (2016) Prevalence of dyslipidemia among elementary school children in Birjand, east of Iran. J. Tehran Univ. Heart Center 11:15-20

23. Palmieri $V$, de Simone $G$, Arnett $D$ et al (2001) Relation of various degrees of body mass index in patients with systemic hypertension to left ventricular mass, cardiac output, and peripheral resistance (the hypertension genetic epidemiology network study). Am J Cardiol 88:1163-1168

24. Khositseth A, Suthutvoravut U, Chongviriyaphan N et al (2007) Cardiac dimensions and function in children with obesity. Indian Heart J 59:142-146

25. Yannoutsos A, Levy Bl, Safar ME, Slama G, Blacher J (2014) Pathophysiology of hypertension: interactions between macro and microvascular alterations through endothelial dysfunction. J Hypertens 32:216-224

26. Kim H, Park J, Kim H et al (2006) Obesity and cardiovascular risk factors in Korean children and adolescents aged 10-18 years. Am J Epidemiol 164 787-793

27. Horri M, Vakili R (2006) Evaluation of cardiovascular and lipid profile abnormalities in obese children and adolescents. IJMS 31(2):87-90

28. Klop B, Elte JWF, Cabezas MC (2013) Dyslipidemia in obesity: mechanisms and potential targets. Nutrients 5:1218-1240

29. Steene-Johannessen J, Kolle E, Reseland JE, Anderssen SA, Andersen LB (2015) Waist circumference is related to low-grade inflammation in youth. Int J PediatrObes 5:313-319

30. Saydah S, Bullard KM, Cheng Y, Ali MK, Gregg EW, Geiss L et al (2014) Trends in cardiovascular disease risk factors by obesity level in adults in the United States, NHANES 1999-2010. Obisity 22(8):1888-1895

\section{Publisher's Note}

Springer Nature remains neutral with regard to jurisdictional claims in published maps and institutional affiliations.

\section{Submit your manuscript to a SpringerOpen ${ }^{\odot}$ journal and benefit from:}

- Convenient online submission

- Rigorous peer review

- Open access: articles freely available online

- High visibility within the field

- Retaining the copyright to your article

Submit your next manuscript at $>$ springeropen.com 